\title{
Geographic variation in hairy dwarf porcupines of Coendou from eastern Brazil (Mammalia: Erethizontidae)
}

\author{
Vilacio Caldara Junior ${ }^{1,2} \&$ Yuri L. R. Leite ${ }^{1}$
}

\author{
${ }^{1}$ Laboratório de Mastozoologia e Biogeografia, Departamento de Ciências Biológicas, Universidade Federal do Espírito Santo. \\ Avenida Marechal Campos 1468, Maruípe, 29043-900 Vitória, ES, Brazil. \\ ${ }^{2}$ Corresponding author. Current address: Instituto Federal de Educação, Ciência e Tecnologia do Espírito Santo, Campus \\ Santa Teresa, Rodovia ES080, km 21, São João de Petrópolis, 29660-000 Santa Teresa, ES, Brazil. \\ E-mail: vcaldarajr@gmail.com
}

\begin{abstract}
We evaluated geographic variation in New World porcupines of Coendou (Erethizontidae) from eastern Brazil by analyzing morphological data from museum specimens we identified as Coendou insidiosus and C. spinosus. Coendou insidiosus ranges from the states of Bahia to Espírito Santo, reaching the state of Minas Gerais in Brazil; C. spinosus extends from the states of Minas Gerais and Espírito Santo to the state of Rio Grande do Sul, in Brazil, extending into Paraguay, Uruguay, and northeastern Argentina. Our results indicate that there are three spatially coherent, morphologically distinct groups, which can be diagnosed using a combination of discrete morphological characters, and which are supported by univariate and multivariate statistical analyses. We classified members of the Northern group as $C$. insidiosus, which usually have several pale to light-brown unicolor thin hairs covering the dorsal and lateral quills. They are cranially and externally smaller than the other two groups, and have shorter hairs and quills. Specimens of the Central group are intermediate in terms of body size, and fit the description of $C$. spinosus, which have thick hairs covering the dorsal and lateral quills. These hairs are dark-brown at the base, and grayish, orange, yellow or light brown at the tip. The Southern group has the largest size and we classified it as a geographic variant of C. spinosus based on the conspicuous presence of large quills on the dorsal surface, which vary from yellowish or orange to blackish.
\end{abstract}

KEY WORDS. Atlantic Rainforest; biogeography; morphological variation; Sphiggurus; taxonomy.

Rodents Erethizontidae Bonaparte, 1845 correspond to New World porcupines, commonly known as "ouriços-cacheiros" in Brazil, and are among the most taxonomically neglected New World mammals (Voss 2011). The most recent catalog of living mammals (Woods \& KiLPatrick 2005) lists five genera: Erethizon Cuvier, 1823; Echinoproctra Gray, 1865; Chaetomys Gray, 1843; Coendou Lacépède, 1799; and Sphiggurus Cuvier, 1823. On the other hand, Handley \& Pine (1992), Emmons \& Feer (1997), Voss \& Angermann (1997) considered species of Sphiggurus and Coendou as members of a single genus, Coendou, which is the senior synonym. In the present paper, we follow the most recent taxonomic review of Coendou (Voss 2011), which includes both Echinoprocta and Sphiggurus as its junior synonyms.

The species level taxonomy of Coendou is problematic because many species in this genus were described based only on pelage characters (Ellerman 1966). Voss \& ANGERMAnN (1997) indicated the lack of detailed taxonomic reviews of type material as the main source of confusion regarding the taxonomy of Erethizontidae. They are still poorly understood with respect to the taxonomic status of several taxa and their phylogenetic relationships (Bonvicino et al. 2002). The early descriptions are brief, and precise locality information is, for most part, missing (Voss \& Angermann 1997). Voss \& Angermann (1997) recently reviewed the taxonomy of some porcupine species, and identified and redescribed the actual holotype of $C$. insidiosus. In the most recent review of Coendou, Voss (2011) listed 13 valid species and designated a neotype for C. spinosus.

Here we deal with the geographic variation in hairy dwarf porcupines from the Atlantic Forest of eastern Brazil. The Brazilian porcupine Coendou prehensilis is the largest species in this region, and it is readily identifiable by the lack of hairs covering the long quills (Leite et al. 2011). The smaller and hairier forms, on the other hand, are less conspicuous and much more difficult to identify. For example, Moojen (1952) considered eight species of hairy dwarf porcupines from eastern Brazil, Emmons \& Feer (1997) and Woods \& Kilpatrick (2005) listed three, whereas Cabrera (1961) and Voss (2011) listed only two (Tab. I). Bonvicino et al. (2002) found consistent differences in the karyotypes of porcupine species, including C. insidiosus $(2 \mathrm{n}=$ $62, \mathrm{FN}=76$, according to Lima 1994), and "C. villosus" $(2 \mathrm{n}=42$, 
Table I. Species of hairy dwarf porcupines of Coendou from eastern Brazil according to different authors.

\begin{tabular}{lllcc}
\hline \multicolumn{1}{c}{ Moojen (1952) } & \multicolumn{1}{c}{ CABRERA (1961) } & EMmons \& FeER (1997) & Woods \& KILPATRICK (2005) & Voss (2011) \\
\hline C. insidiosus (Olfer 1818) & C. insidiosus & C. insidiosus & S. insidiosus & C. insidiosus \\
C. spinosus Cuvier, 1823 & Synonyms: & C. spinosus & Synonym: & Synonym: \\
C. villosus Cuvier, 1823 & melanurus (Wagner, 1842) & Synonyms: & pallidus (Waterhause, 1848) & pallidus \\
C. paraguayensis (Oken, 1816) & villosus & villosus & S. spinosus & C. spinosus \\
C. nigricans (Brandt, 1835) & C. spinosus & roberti & Synonyms: & Synonyms: \\
C. affinis (Brandt, 1835) & Synonyms: & C. paragayensis & paragayensis & villosus \\
C. sericeus Cope, 1889 & paraguyensis & & nigricans & nigricans \\
C. roberti (Thomas, 1902) & couiy Desmarest, 1822 & & affinis & sericeus \\
& nigricans & & sericeus & roberti \\
& affinis & roberti & couiy \\
& sericeus & S. villosus & affinis \\
& roberti & & paragayensis \\
\hline
\end{tabular}

a Subspecies of S. insidiosus from Northern Brazil, following Cabrera (1961) and Husson (1978). Other authors considered Amazonian S. melanurus as a distinct species.

b Specific epithet unavailable, following Voss \& Angermann (1997).

$\mathrm{FN}=75-76$, according to Bonvicino et al. 2000) from eastern Brazil, confirming that these taxa represent distinct species. The distribution of $C$. insidiosus ranges from the state of Sergipe southward to the state of Rio de Janeiro, including the eastern part of the state of Minas Gerais, whereas the distribution of $C$. spinosus is from the state of Espírito Santo southward to the state of Rio Grande do Sul, including Paraguay, northern Uruguay and northeastern Argentina (Voss 2011). Species level identification of porcupines is very difficult where they overlap, because species boundaries are poorly defined and there is strong phenotypic variation among specimens. Here, we evaluated the geographic variation in hairy dwarf Coendou specimens from eastern Brazil to better understand species limits and intraspecific variation. We analyzed morphological and morphometrical variation across their distributional ranges, clustered specimens into groups, recorded diagnostic characters for these groups, and associated these groups with species names available in the literature.

\section{MATERIAL AND METHODS}

We analyzed 182 specimens of Coendou spp. (180 skulls and/or skins and two whole specimens in fluid) from eastern Brazil, which were housed in scientific collections (see Appendix for a complete list of specimens examined). We recorded all data on specimens' tags, including external measurements $(\mathrm{TOL}=$ total length, TAL $=$ tail length, $\mathrm{HFL}=$ hind foot length, $\mathrm{EAR}=$ ear length, $\mathrm{W}=$ weight). Specimens examined are housed in the following collections in Brazil: Museu de Biologia Professor Mello Leitão, Santa Teresa, Espírito Santo (MBML); Museu de Ciências Naturais, Fundação Zoobotânica do Rio Grande do Sul, Porto Alegre, Rio Grande do Sul (MCNFZB); Museu de
História Natural Capão da Imbuia, Curitiba, Paraná (MHNCI); Museu Nacional, Universidade Federal do Rio de Janeiro, Rio de Janeiro (MN); Museu de Zoologia, Universidade de São Paulo, São Paulo (MZUSP); Departamento de Ciências Biológicas, Universidade Federal do Espírito Santo, Vítória, Espírito Santo (UFES); Departamento de Zoologia, Universidade Federal de Minas Gerais, Belo Horizonte, Minas Gerais (UFMG). Geographic coordinates of collecting localities were obtained from specimens' tags, or from Paynter \& Traylor (1991), Vanzolini (1992), and Geobusca (2007). We used ArcView 3.2 software (developed by ESRI 1992-1999) to map collecting localities and to draw geographic distribution maps.

Specimens were classified into four heuristic ages (juvenile, sub-adult, adult, old adult). We considered maxillary tooth eruption, cranial bone sutures and pelage maturation (Figs 1-6), following Voss \& Angermann (1997), to decide on the stage of development. Eleven specific pelage characters were scored, in addition to general appearance. We collected one hair and one quill from the mesodorsal region of each specimen. We measured hair length (LH) and length of quill (LQ). These measurements were recorded using a caliper, to the nearest $0.01-\mathrm{mm}$. We analyzed the following fur characters: color of dorsal hair base; color of dorsal hair tip; presence of tricolor quills; position of tricolor quills; color proportions on tricolor quills; color of tricolor quill tip; color of vibrissae tip; color of ventral hair base; color of ventral hair tip; color of ventral bristles on the tail; proportion of colors of ventral bristles on the tail.

Twenty-two discrete cranial characters were analyzed and some of them were illustrated (Figs 7-12). We chose these cranial structures after observing marked variation on their morphology during a preliminary examination of some specimens. 

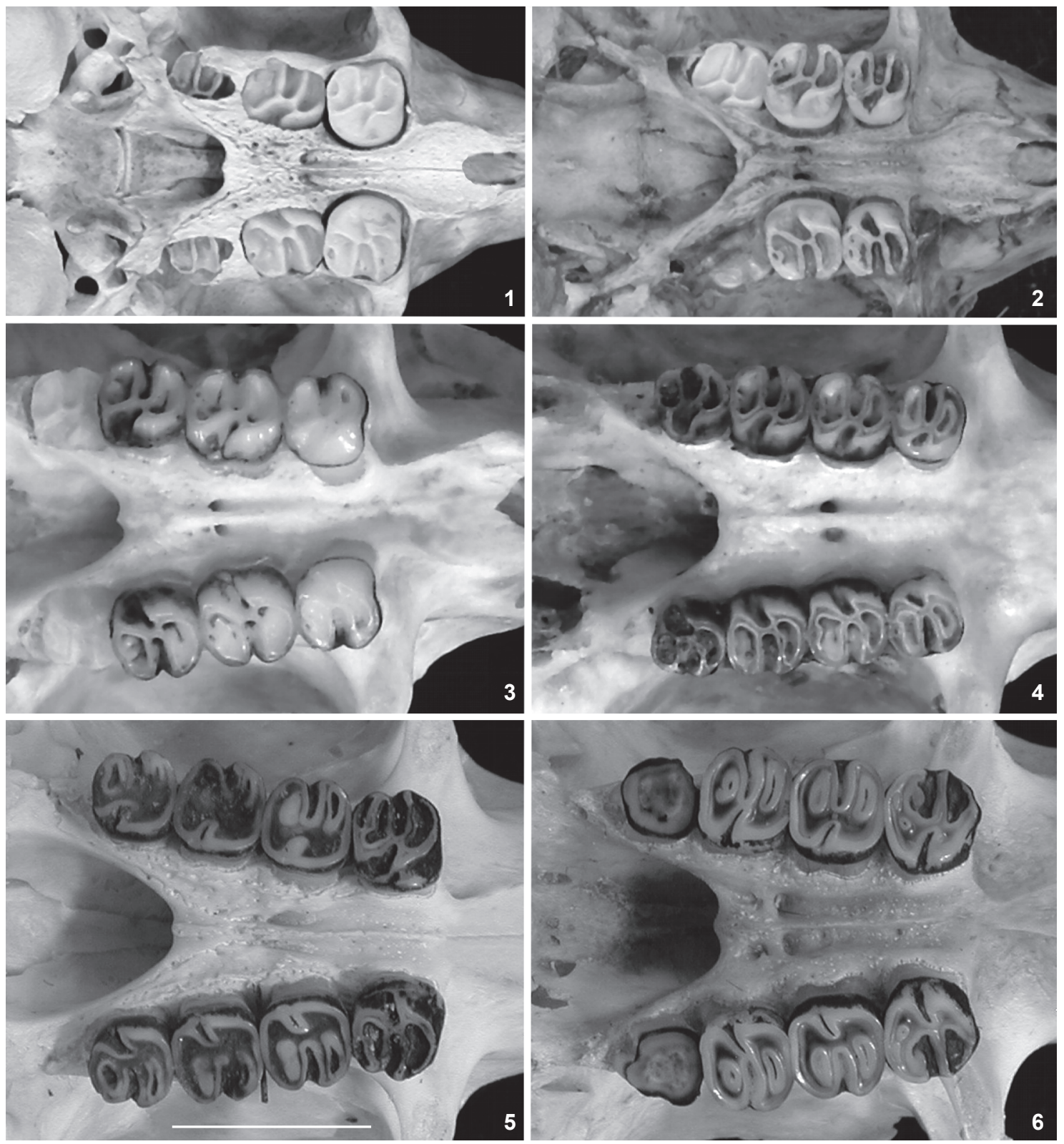

Figures 1-6. Age categories of Coendou based on maxillary tooth eruption: (1-3) juvenile; (4) subadult; (5) adult; (6) old. Scale bar: $1.0 \mathrm{~cm}$.

We followed Moraes-SANTOS (1997) for trait nomenclature: length of anterior nasal extremity compared to dorsal pre-maxillary extremity; inclination of nasal/pre-maxillary suture compared to maxillary toothrow; shape of nasal/frontal suture; presence of lacrimal spine; presence of parietal spine; angle formed by zygomatic arch in dorsal view; shape of incisive foramen; breadth of maxillary crest compared to palatine breadth; shape of mesopterygoid fossa; anteriormost position of mesopterygoid fossa compared to molar toothrow; size of sphe- nopalatine fossa; shape of infraorbital foramen; inclination of infraorbital foramen in lateral view compared to maxillary toothrow; length of gnathic process; number of canals in ethmoidal foramen; position of lacrimal/sphenoid suture compared to sphenofrontal foramen; depth of occipital condyle/ paraoccipital process depression; shape of occipital condyle/ paraoccipital process depression; breadth of basioccipital comparing to auditory bullae; shape of occipital ridge; size of subsquamosal fenestra; size of coronoid process. 

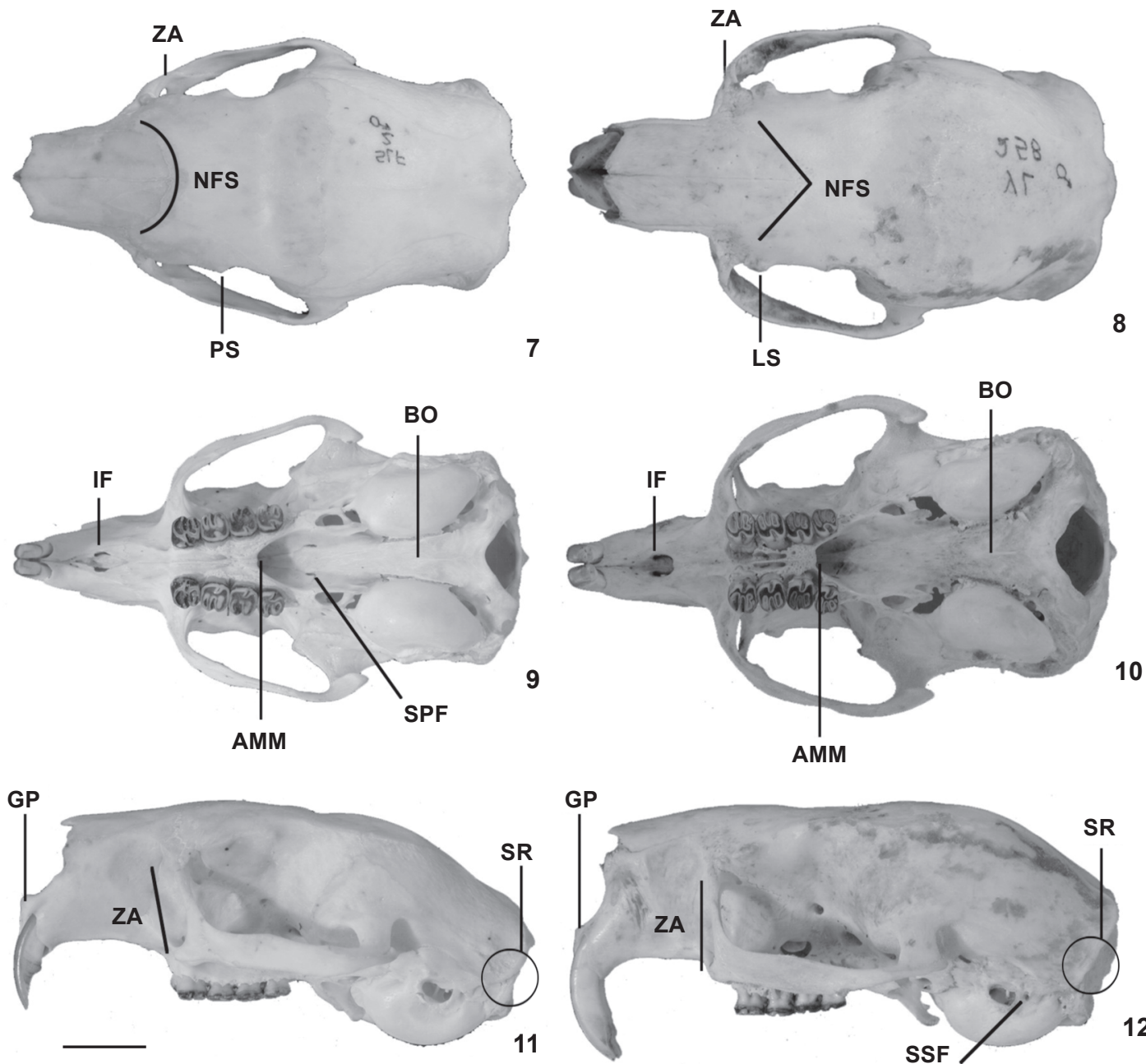

Figures 7-12. Cranial morphology of Coendou: (7-8) dorsal view; (9-10) ventral view; (11-12) lateral view. (ZA) Zygomatic arch weakly arched (7) or strongly arched (8), diagonal (11) or perpendicular compared to maxillary toothrow (12); (NFS) naso/frontal suture "U"shaped (7) and " $\mathrm{V}$ "-shaped (8); (PS) parietal spine present (7); (LS) lacrimal spine present (8); (IF) incisive foramen fusiform (9) and ovate (10); (BO) basioccipital narrow (9) and wide (10); (AMM) mesopterygoid fossa " $U$ "-shaped (9) or trapezoidal (10) and reaching level of $2^{\text {nd }}$ and $3^{\text {rd }}$ molars (9-10); (SPF) sphenopalatine fossa evident (9); (GP) gnatic process long (11) and short (12); (SR) sagittal ridge delicate (11) and robust (12); (SSF) subsquamosal fenestra evident (12). Scale bar: $1.0 \mathrm{~cm}$.

We took 21 cranial measurements (Figs 13-16) using a digital caliper to the nearest $0.01 \mathrm{~mm}$. Measurements follow Voss \& SILVA (2001), except for length of auditory bulla (LAB, measured from the basioccipital suture to the extremity of the auditory bulla process), length of dentary (LDE, measured from posterior extremity of angular process to anterior margin of incisor alveolus) and height of dentary (HDE, distance from ventral extremity of angular process to posterior extremity of condyloid process), which were chosen after preliminary observation of potential variation among specimens. The remaining measurements are: $\mathrm{LN}$ - length of nasals, $\mathrm{BB}$ - breadth of braincase, LD length of diastema, PZB - posterior zygomatic breadth, APB - anterior palatal breadth, PPB - posterior palatal breadth, CIL condylo-incisive length, ZL - zygomatic length, BNA - breadth of nasal aperture, HIF - height of infraorbital foramen, LIF length of incisive foramen, BIF - breadth of incisive foramen, BIT - breadth of incisor tips, DI - depth of incisor, MTR - maxillary toothrow length, LM - length of molars, BP4 - breadth fourth pre-molar, BM1 - breadth of first molar.

Only adult specimens (including both adult and old adult age categories) were used in the analyses of morphological and morphometric characters. In addition, we only included specimens with known specific collecting localities. We analyzed males and females together because of small sample sizes, and 

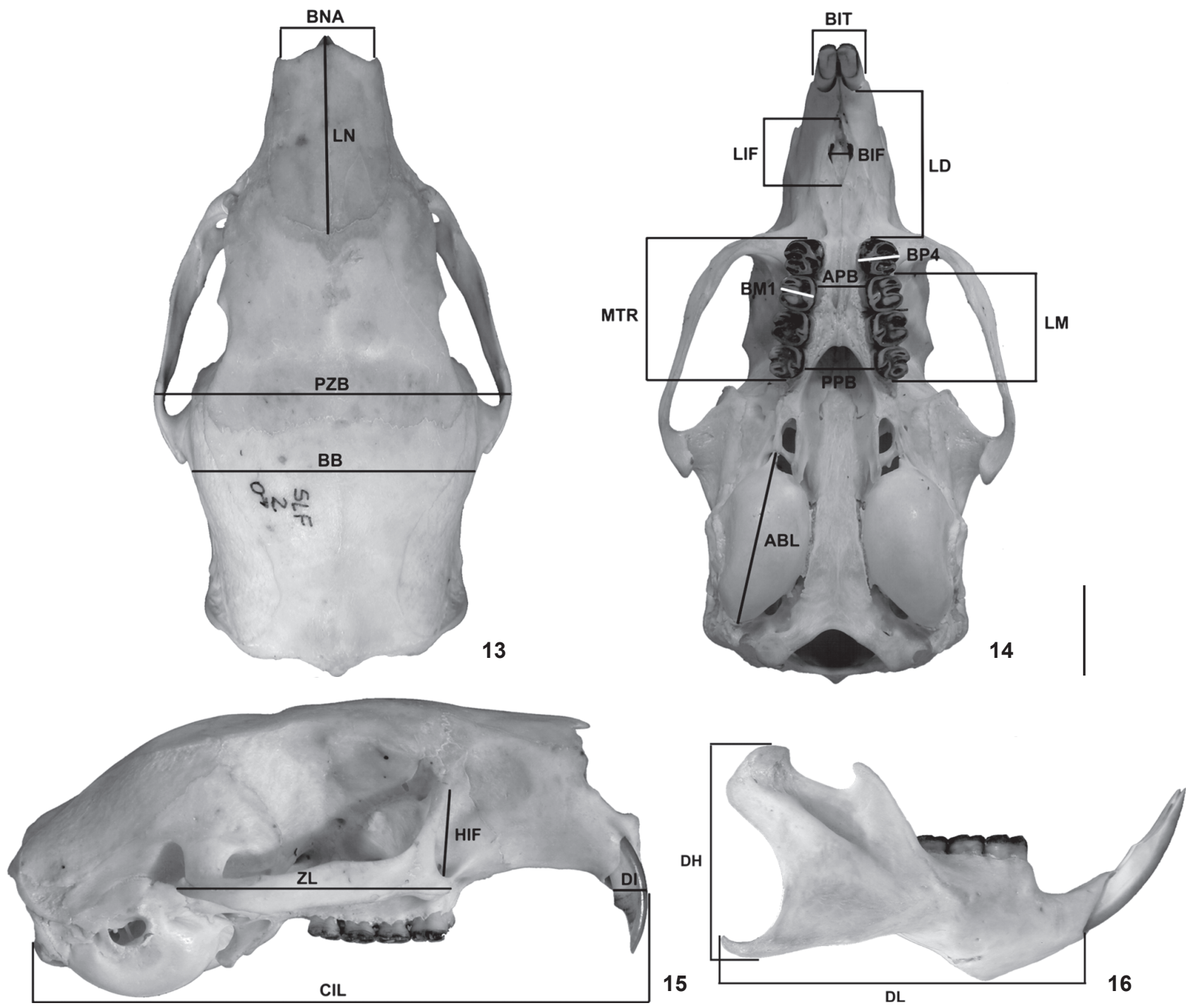

Figures 13-16. Skull measurements of Sphiggurus: (13) dorsal view; (14) ventral view; (15) lateral view; (16) dentary. For abbreviations see materials and methods. Scale bar: $1.0 \mathrm{~cm}$.

after considering that we had found no sexual dimorphism in a few samples examined in previous exploratory analyses. We first classified specimens with skull and skin into groups based on pelage characters, so that members of each group shared the same pelage characters. We then used cranial morphology to look for diagnostic cranial characters for each group.

The software PAST (developed by HAMMER et al. 2001) was used to analyze morphometric data. In these analyses, we included measurements of four C. insidiosus specimens (including the holotype of Hystrix insidiousus) from Voss \& ANGERManN (1997). For each group, we calculated basic descriptive statistics for each measurement: mean, standard deviation (sd), range, and sample size. We checked for normality using
Kolmogorov-Smirnov test and we used only variables with normal distributions in the remaining statistical analyses. Measurements were transformed to base 10 logarithms for the multivariate statistical analyses (according to SOKAL \& ROHLF 1995).

Discriminant function analysis was used to investigate how morphometric cranial data discriminate the groups designated a priori. In this analysis, we included only specimens that had data for all cranial morphometric variables, except those variables that are absent or incomplete in Voss \& Angermann (1997: LN, LAB, BNA, LIF, BIF, LDE, LH). We used only specimens with skull and skin preserved to generate discriminant functions because the a priori group classification 
was based on pelage characters. The t-test was employed to check for significant differences of variable means between pairwise groups, using a p-level of $5 \%(\mathrm{p}<0.05)$. We also used analysis of variance (ANOVA) to check for significant differences of variable means among all groups, using a p-level of $5 \%(\mathrm{p}<0.05)$. We used principal component analysis (PCA) to reduce data redundancy, to find possible morphometric clusters in the sample, and to view multivariate trends.

A Euclidean distance matrix with geographic distances among collecting localities was generated using the software PAST (developed by HAMmer et al. 2001). We also generated distance matrices for cranial morphometric variables as a whole (multivariate), and for each cranial variable individually (univariate). These matrices were generated for the total sample and for each group of specimens separately. We tested the correlation between geographic distance and morphometric distance for the total sample and for each group individually using the Mantel test, described in SoKal \& Rohlf (1995). We did 1,000 random runs using the software. We considered significant $\mathrm{p}$ levels below $2.5 \%$ and above $97.5 \%(\mathrm{p}<0.025$ and $\mathrm{p}>0.975)$, because the Mantel test is two-tailed.

\section{RESULTS}

We found ample phenotypic variation in pelage characters among individuals of Coendou ranging from the state of Bahia to the state of Rio Grande do Sul, eastern Brazil (Fig. 17). The dorsal hair base varies among pale, light-brown and darkbrown, and dorsal hair tips are grayish, pale, yellow, orange, light-brow or dark-brown. When present, tricolor quills can be found on the head only, from head to the shoulders, along the mesodorsal or lumbar regions. We found two color patterns in tricolor quills: yellow base longer than equally sized black middle, and orange tip; or equally sized yellow base and black center, both longer than orange tip (Figs 18-21). Some specimens had yellow-tipped quills. Vibrissae tip color varies among grayish, yellow, light- and dark-brown. Ventral hair base is either light or dark-brown, whereas hair tip varies among pale, yellow, orange, and dark-brown. The base of the ventral tail bristles is always dark-brown, whereas its tip varies among pale, yellow, orange and dark-brown. We found three color patterns in the ventral bristles of the tail: equally sized basal and apical portions; basal portion twice the length of apical portion; basal portion three times longer than apical portion.

We separated specimens into three groups based on the general aspect of the pelage. These three groups are geographically structured, and we named them accordingly as Northern, Central, and Southern groups (Figs 17 and 22-27). We then evaluated which specific pelage characters could be used to diagnose these groups (Tab. II).

The main diagnostic character of specimens of the Northern group is the presence of many slender and almost straight unicolored dorsal hairs, covering both dorsal and lateral quills

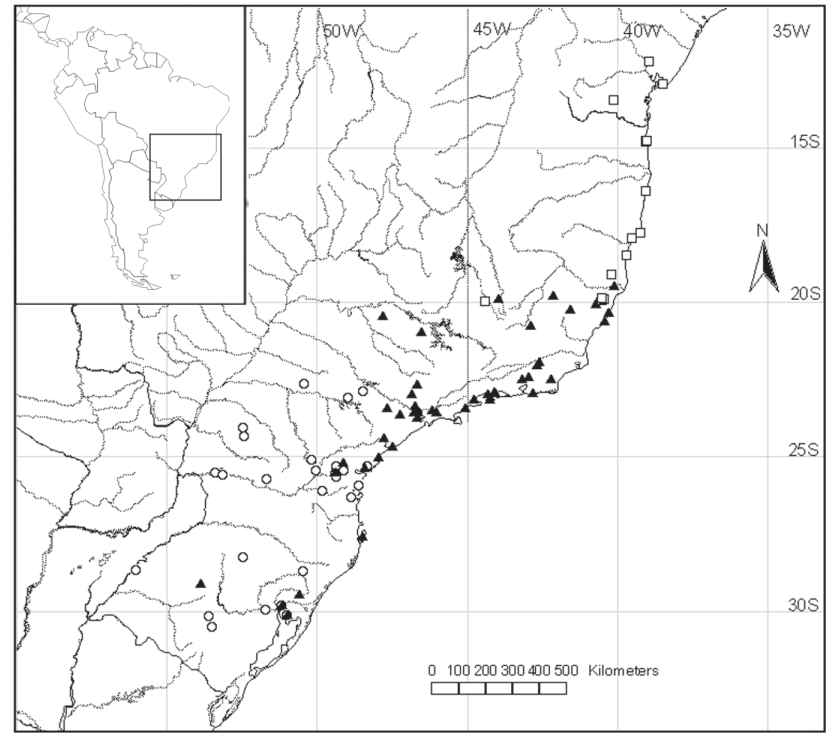

Figure 17. Collecting localities of Coendou spp.: ( $\square$ ) Northern group (C. insidiosus); ( $\mathbf{\Delta})$ Central group (C. spinosus); (O) Southern group (C. spinosus).

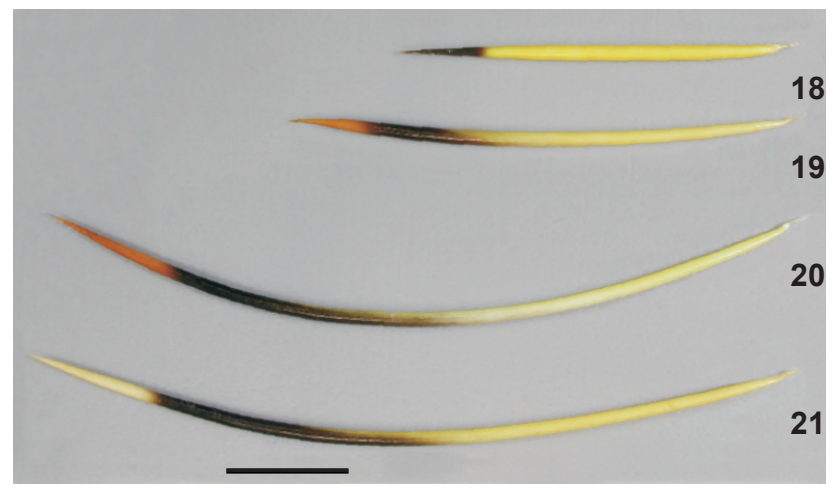

Figures 18-21. Mesodorsal quills of Coendou spp. from eastern Brazil: (18) short yellow-based, black-tipped bicolor quill (Northern group, C. insidiosus); (19) short tricolorquill with yellow base longer than black middle and orange tip (Central group, C. spinosus); (20) long tricolor quill having equally-sized yellow and black bands longer than orange tip (Southern group, C.spinosus); (21) long tricolor quill with yellow tip (Southern group, C. spinosus). Scale bar: $1.0 \mathrm{~cm}$.

homogeneously. These hairs hide the quills and give a regular texture to the pelage. Many specimens of the Northern group have light dorsal pelage, with uniformly pale (Figs 22 and 23) or light-brown (Figs 28 and 29) hairs, but some specimens have dark dorsal pelage because of the presence of uniformly darkbrown hairs throughout (Figs 30 and 31). Some specimens of the Northern group have tricolor quills, but these quills never extend beyond the shoulders. The ventral bristles on the tail 


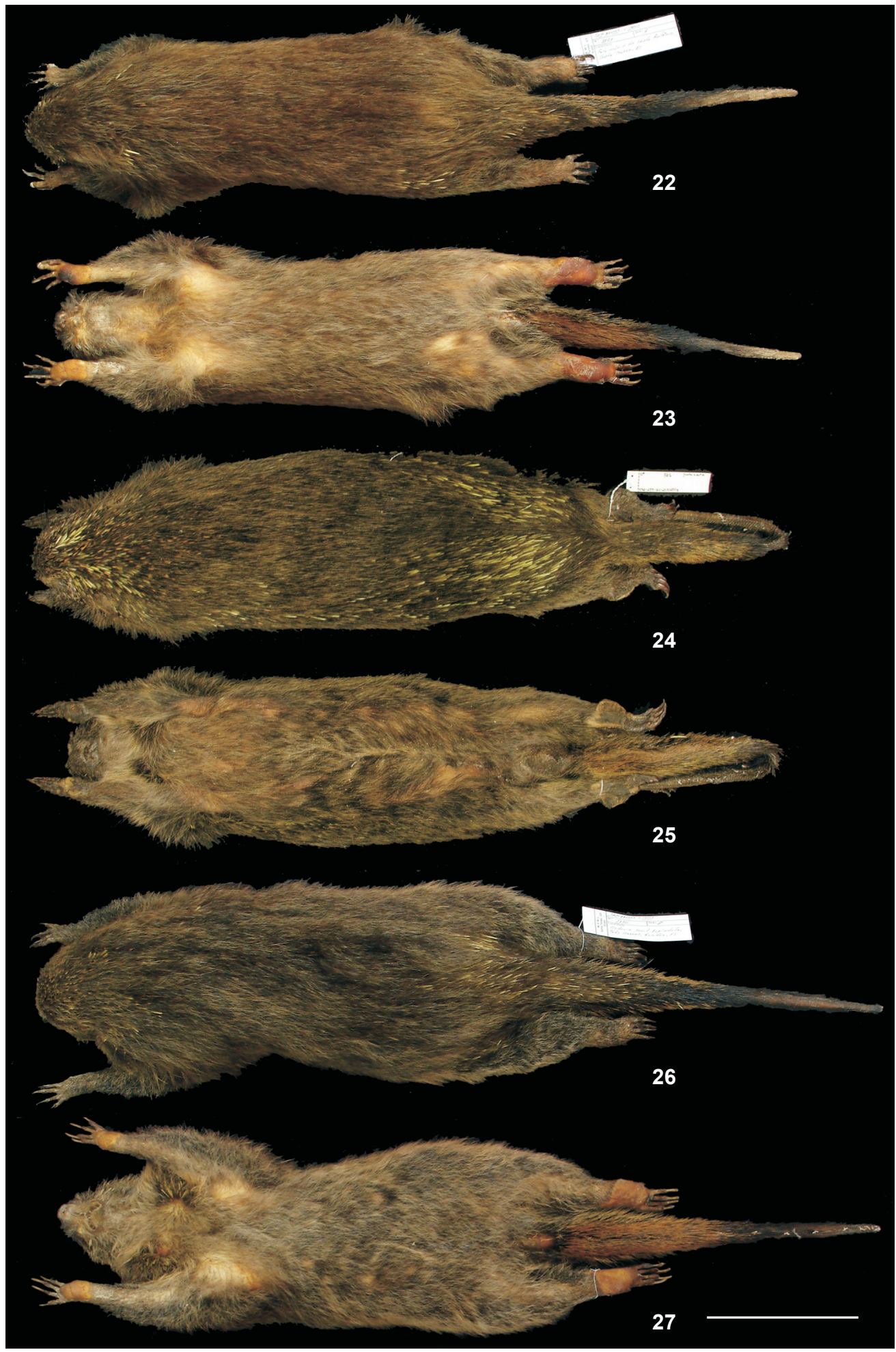

Figures 22-27. Pelage of Coendou spp. from eastern Brazil: Northern group (C. insidiosus) in dorsal (22) and ventral (23) views; Central group (C. spinosus) in dorsal (24) and ventral (25) views; Southern group (C. spinosus) in dorsal (26) and ventral (27) views. Scale bar: $1.0 \mathrm{~cm}$. 




Figures 28-31. Pelage color variation in the Northern group (C. insidiosus): light-brown, in dorsal (28) and ventral (29) views; darkbrown, in dorsal (30) and ventral (31) views. Scale bar: $10.0 \mathrm{~cm}$.

are either uniformly dark-brown or have pale or yellow tips. Specimens of the Northern group range from Salvador, in the state of Bahia, to the central region of the state of Espírito Santo, extending west into northeastern state Minas Gerais (Fig. 17).

Specimens of the Central group can be diagnosed by the presence of many bicolored dorsal hairs, which are longer, thicker, and wavier than those in members of the Northern group. These hairs cover the dorsal and lateral quills homogeneously, and give the pelage a shaggy aspect. The color of the dorsal hair base is always dark-brown in members of the Central group, and the hair tips range among grayish (Figs 24 and 25), orangish (Figs 32 and 33), yellow (Figs 34 and 35) or lightbrown (Figs 36 and 37). Tricolor quills are always present from the head to the mesodorsal or lumbar regions. The yellow base 


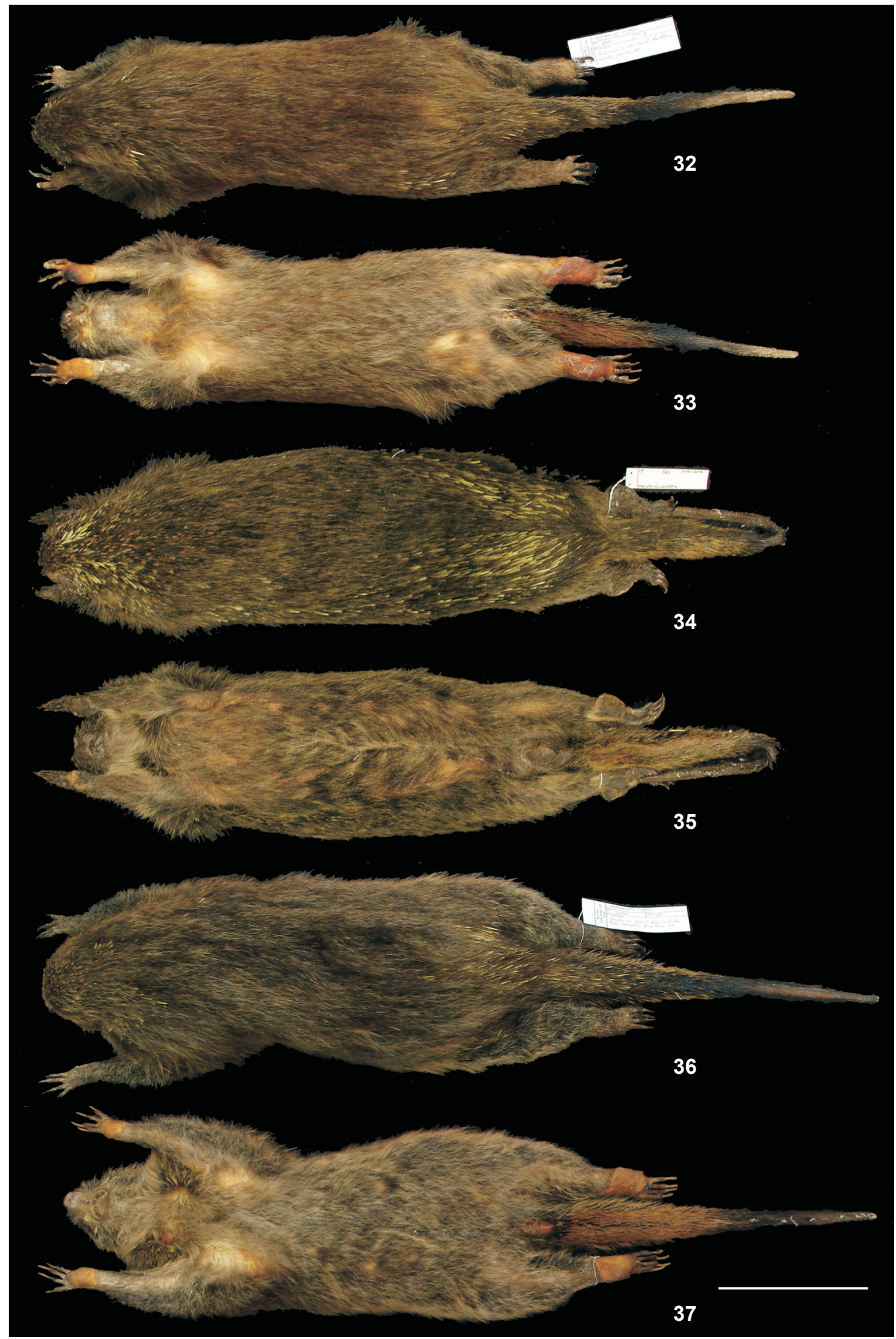

Figures 32-37. Pelage color variation in the Central group (C. spinosus): dorsal hairs orange tipped, in dorsal (32) and ventral (33) views; yellow tipped, in dorsal (34) and ventral (35) views; and light-brown tipped, in dorsal (36) and ventral (37) views. Scale bar: $10.0 \mathrm{~cm}$. 
of the quill is longer than the black and orange bands in almost every mesodorsal quill (Fig. 19). The ventral bristle tips on the tail are usually orange, and sometimes yellow. Individuals of the Central group have been collected from the central region of the state of Espírito Santo to the state of Rio Grande do Sul, extending into eastern state of Minas Gerais (Fig. 17).

Members of the Southern group have few bicolored dorsal hairs covering both dorsal and lateral quills. Their dorsal hairs are very similar to those from members of the Central group. These hairs do not cover the dorsal surface homogeneously, forming sparse tufts. Thus, dorsal color variation in members of the Southern group is caused mainly by variation of quill color, in contrast with individuals of the other two groups, in which dorsal color patterns are mainly due to variation of hair color. The dorsal color of members of the Southern group varies among darkish (Figs 26 and 27), yellowish (Figs 38 and 39), and orange (Figs 40 and 41). Tricolored quills are present in every specimen examined, and they cover the dorsal surface completely. The yellow and black bands are equally sized and longer than the orange tip on mesodorsal quills, but some specimens have yellow-tipped quills (Fig. 21). The tips of the ventral bristles on the tail are usually yellow, but some specimens have orange tips. The Southern group ranges from the northeastern portion of the state of São Paulo to the state of Rio Grande do Sul (Fig. 17).

We also identified great variation in cranial morphology among Coendou specimens. No cranial character alone is diagnostic for any group, and many cranial structures show variation in character states along the geographic distribution of the species. The anterior nasal extremity is either short or long compared to the dorsal pre-maxillary extremity in individuals of the Central and Southern groups, being short in all specimens from the Northern group (Tab. II). The nasal/pre-maxillary suture is usually diagonal compared to maxillary toothrow, but it is horizontal in some individuals. The nasal/frontal suture is usually " $U$ "-shaped (Fig. 7), but it is sometimes "V"shaped (Fig. 8). Lacrimal and parietal spines are either present or absent (Figs 7 and 8). The lacrimal spine is present in many individuals from the Central and Southern groups, but it is present in only one specimen from the Northern group (Tab. II). Zygomatic arch can be curved or not in dorsal view (Figs 7 and 8). The incisive foramen is either ovate or fusiform (Figs 9 and 10). The maxillary crest ranges from narrower to wider than the palatine. The mesopterygoid fossa is usually " $U$ "shaped (Fig. 9) or trapezoidal (Fig. 10), but it is "V"-shaped in some individuals. The mesopterygoid fossa is either posterior

Table II. Diagnostic characters of the three groups of Coendou from eastern Brazil identified in the present paper.

\begin{tabular}{|c|c|c|c|}
\hline Character & Northern group (C. insidiosus) & Central group (C. spinosus) & Southern group (C. spinosus) \\
\hline Hairs covering quills & Homogeneously abundant & Homogeneously abundant & Heterogeneously scarce \\
\hline Texture & Smooth & Shaggy & Shaggy \\
\hline Color of dorsal hair base & Pale, light or dark brown & Dark brown & Dark brown \\
\hline Color of dorsal hair tips & Pale, light or dark brown & $\begin{array}{l}\text { Grayish, orangish, yellow or light- } \\
\text { brown }\end{array}$ & $\begin{array}{l}\text { Grayish, orangish, yellow or light- } \\
\text { brown }\end{array}$ \\
\hline Tricolor quills & $\begin{array}{l}\text { From head to shoulders, when } \\
\text { present }\end{array}$ & $\begin{array}{l}\text { From head to mesodorsal or lumbar } \\
\text { region }\end{array}$ & From head to lumbar region \\
\hline Mesodorsal tricolor quills & Absent & $\begin{array}{l}\text { Yellow base longer than black and } \\
\text { orange bands }\end{array}$ & $\begin{array}{l}\text { Yellow and black bands longer than } \\
\text { orange tip }\end{array}$ \\
\hline Color of tricolor quill tip & Orange & Orange & Orange or yellow \\
\hline $\begin{array}{l}\text { Color of bristle tips on ventral side } \\
\text { of tail }\end{array}$ & Uniformly dark brown or yellowish & Usually orangish & Usually yellowish \\
\hline Length of mesodorsal quills & Short $(35.17 \pm 3.50 \mathrm{~mm})$ & Medium (45.65 $\pm 9.63 \mathrm{~mm})$ & Long $(57.74 \pm 4.80 \mathrm{~mm})$ \\
\hline Head and body length & Small to medium $(581.71 \pm 49.34 \mathrm{~mm})$ & $\begin{array}{l}\text { Small to medium ( } 600.85 \pm \\
56.13 \mathrm{~mm})\end{array}$ & Medium to large $(655.31 \pm 33.69 \mathrm{~mm})$ \\
\hline Anterior nasal extremity & Short & Short or long & Short or long \\
\hline Lacrimal spine & Usually absent & Usually present & Usually present \\
\hline Sphenopalatine fosse & Subtle or evident & Subtle or evident & Usually evident \\
\hline Infraorbital foramen & Triangular or ovate & Triangular or ovate & Usually ovate \\
\hline Occipital ridge & Delicate or robust & Delicate or robust & Usually robust \\
\hline $\begin{array}{l}\text { Skull length (condylo-incisive } \\
\text { length) }\end{array}$ & Short to medium $(68.42 \pm 3.30 \mathrm{~mm})$ & Medium to large $(72.84 \pm 2.97 \mathrm{~mm})$ & Medium to large $(73.52 \pm 2.99 \mathrm{~mm})$ \\
\hline $\begin{array}{l}\text { Skull width (posterior zygomatic } \\
\text { breadth) }\end{array}$ & Narrow $(41.61 \pm 2.32 \mathrm{~mm})$ & Medium (44.19 $\pm 1.80 \mathrm{~mm})$ & Wide $(45.13 \pm 1.68 \mathrm{~mm})$ \\
\hline Maxillary toothrow length & Short $(14.55 \pm 0.70 \mathrm{~mm})$ & Medium (15.86 $\pm 0.72 \mathrm{~mm})$ & Long $(16.39 \pm 0.68 \mathrm{~mm})$ \\
\hline
\end{tabular}






Figures 38-41. Pelage color variation in the Southern group (C. spinosus): yellowish specimen, in dorsal (38) and ventral (39) views; and orange specimen, in dorsal (40) and ventral (41) views. Scale bar: $10.0 \mathrm{~cm}$.

or anterior to the contact of the third and second molars. The sphenopalatine fenestra is either subtle or evident (Fig. 9). The infraorbital foramen is either triangular or ovate in anterior view. The infraorbital foramen can be perpendicular or diago- nal comparing to the maxillary toothrow in lateral view (Figs 11 and 12). Specimens of the Southern group have usually triangular sphenopalatine fossa and ovate infraorbital foramen (Tab. II). The gnathic process is either short or long (Figs 11 
and 12). The ethmoidal foramen is usually formed by a single canal, but a double canal is found in some individuals. The lacrimal/sphenoid suture ranges from far from, to near or fused to, the sphenofrontal foramen. The occipital condyle/ paraoccipital process depression is usually deep and " $U$ "-shaped, but it is sometimes flat and "V"-shaped. The basioccipital is either wide or narrow compared to the auditory bulla (Figs 9 and 10), and the occipital ridge is either delicate or robust (Figs 11 and 12) in the Northern and Central groups, but it is usually robust in the Southern group (Tab. II). The subsquamosal fenestra is either minute or evident (Fig. 12), and the coronoid process ranges from short to long.

The discriminant function analysis based on cranial measurements supported the groups designated a priori using only pelage characters. All specimens used for generating the discriminant function $(n=58)$ were correctly classified a posteriori. The first discriminant function (DF 1) contributed $68.36 \%$ to the variation and segregated specimens from the Northern and Southern groups, whereas the Central group was intermediate (Fig. 42). The second discriminant function (DF 2) contributed $31.64 \%$ and was not successful in clustering the three groups. We used the discriminant functions to classify specimens preserved as skulls only into each group, and included them in subsequent statistical analyses as members of those groups.



Figure 42. Bivariate plot of scores for two discriminant functions (and their eigenvalues) in comparisons of Coendou spp. (n) Northern group (C. insidiosus); (c) Central group (C. spinosus); (s) Southern group (C. spinosus). Arrow indicates the holotype of $C$. insidiosus. (DF 1) Discriminant Function 1, (DF 2) Discriminant Function 2.

The t-test and ANOVA showed significant differences among groups for most external and cranial measurements (Tab. III). Four measurements are significantly different among the three groups simultaneously using both t-test and ANOVA: posterior zygomatic breadth (PZB), maxillary toothrow length (MTR), length of quills (LQ), breadth of nasal aperture (BNA). In the first three of these measurements, values from the Northern group are smaller than those from the Central group, which are in turn smaller than those from the Southern group. This was the general trend for most measurements (Fig. 43). Using ANOVA, we found significant differences in five measurements : breadth of incisive foramen (BIF), length of dentary (LDE), total length (TOL), tail length (TAL) and hind foot length (HFL). In spite of similar external measurements, specimens of the Northern group have shorter and narrower skull, auditory bullae, zygomatic bones, nasal aperture, maxillary toothrow, molars and hairs, shorter quill, and narrower incisors than members of the Central group. Specimens of the Central group have shorter dentary, maxillary toothrow, and quills, narrower skull, incisive foramen, posterior palatal region, fourth pre-molars and first molars when compared to specimens from the Southern group. The Southern group is characterized by longer body, tail, and feet, and heavier body when compared to the Central group.



Figure 43. Ratio diagram comparing the mean value for each cranial measurement among Coendou spp. (O) Northern group ( $C$. insidiosus), ( $\square$ ) Central group (C. spinosus), $(\triangle)$ Southern group (C. spinosus). See text for measurement abbreviations.

The first principal component (PC 1) explains $27.57 \%$ of the variation and the second principal component (PC 2) explains $12.19 \%$ (Fig. 44). All variables contributed positively to PC 1, except length of dentary (Fig. 44). Thus, the first principal component is related to variation in cranial size. The variables that most contributed to PC 1 were condylo-incisive length (0.840), zygomatic length (0.767), maxillary toothrow length (0.708), and breadth of incisive foramen (0.693). The 

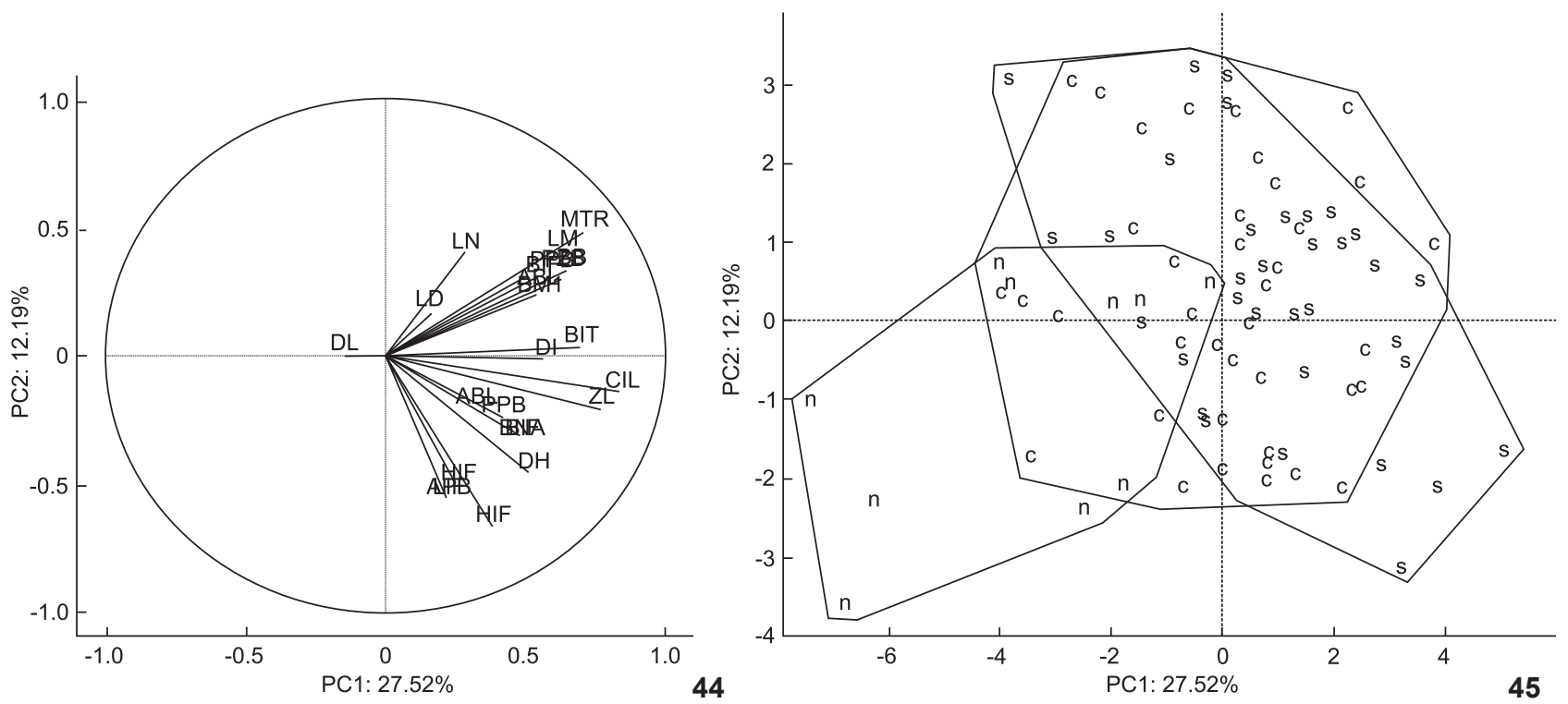

Figures 44-45. (44) Variable projections along first and second principal components (PC 1 and PC 2) extracted from cranial measurements of Coendou spp.; (45) Bivariate plot of PC 1 and PC 2 scores for each specimen. (n) Northern group (C. insidiosus); (c) Central group (C. spinosus); (s) Southern group (C. spinosus).

other principal components had both positive and negative variable contributions (Figs 1-6), and are thus related to variation in cranial shape.

The principal component analysis showed no evident grouping among specimens of Coendou in any principal component combination. Nevertheless, specimens of the Northern group are negatively distributed along PC 1, whereas most members of the Southern group are positively distributed along this axis, and members of the Central group fell between them. This confirms that specimens from the Northern group are smaller than those from the Central group, which are in turn smaller than members of the Southern group. The Mantel test showed a significant positive correlation between geographic distance and phenetic distance of most cranial measurements (BB, PZB, CIL, ZL, BIF, BIT, MTR, LM, BP4, BM1), both individually and when all specimens were analyzed together (Tab. IV). Using the same dataset, we also found a positive significant correlation between geographic distance and phenetic distance variation when all cranial variables were considered together. When we used the Mantel test to analyze test differences by group, we found a positive significant correlation between geographic distance and only two cranial measurements individually (BIT and MTR) in the Northern group. The other groups showed no significant positive correlation among matrices.

\section{DISCUSSION}

ELLERMAN (1966) suggested that cranial characters are not efficient in distinguishing species of Coendou because of the high level of intraspecific variation. The present study confirms such claim by showing the disparity in skull morphology among a representative sample of specimens of Coendou from eastern Brazil. None of the discrete cranial characters scored could be used alone to diagnose the groups defined by pelage characters, although these groups were later supported by discriminant function analysis based on cranial measurements.

The principal component analysis demonstrated that skull size (represented by PC 1) is more important than skull shape (represented by other principal components) for distinguishing among groups. MARRoig \& Cheverud (2005) proposed that changes in skull size occur before than changes in skull shape. Morphometric cranial alterations may represent a source for speciation, even if these alterations are non-adaptive (Marroig \& Cheverud 2005). Size changes in body structures need some morphological adjustment to function efficiently (Marroig \& Cheverud 2004), then becoming adaptive.

Mantel tests revealed a positive significant correlation between geographic distance and phenetic distance when all specimens of Coendou were analyzed together, but not when each of the three groups was evaluated separately. Studies evaluating the constancy or proportionality of genetic and phenotypic correlation matrices for morphological traits suggest that phenotypic patterns are generally a good estimate of their genetic counterparts (see Marroig \& Cheverud 2001). Thus, assuming that phenotypic differences among each group of specimens are largely a consequence of their genotypes, genotypic variation is correlated with geographic distance when all specimens of Coendou from eastern Brazil are taken into ac- 
Table III. Descriptive statistics of external and cranial measurements of Coendou spp. from eastern Brazil. See text for measurement abbreviations. Significant differences among the three groups indicated by the t-test are in bold: (Min.) minimum value, (Max.) maximum value, $\left({ }^{* *}\right) \mathrm{p}<0.01,\left({ }^{*}\right) \mathrm{p}<0.05$, (ns) non significant, (n) sample size, (sd) standard deviation.

\begin{tabular}{|c|c|c|c|c|c|c|c|c|c|c|c|c|c|c|c|c|c|c|}
\hline \multirow{2}{*}{ Variables } & \multicolumn{6}{|c|}{ Northern group (C. insidiosus) } & \multicolumn{6}{|c|}{ Central group (C. spinosus) } & \multicolumn{6}{|c|}{ Southern group (C. spinosus) } \\
\hline & Mean & sd & Min. & Max. & $\mathrm{n}$ & $\mathrm{p}$ & Mean & sd & Min. & Max. & $\mathrm{n}$ & $\mathrm{p}$ & Mean & sd & Min. & Max. & $n$ & $\mathrm{p}$ \\
\hline LN & 22.37 & 1.95 & 19.00 & 24.82 & 9 & ns & 23.10 & 1.99 & 19.34 & 26.82 & 35 & ns & 22.71 & 1.60 & 19.50 & 26.45 & 32 & ns \\
\hline LD & 18.81 & 1.35 & 15.60 & 20.40 & 10 & ns & 18.58 & 1.74 & 14.40 & 22.47 & 39 & ns & 18.45 & 1.12 & 16.21 & 20.56 & 34 & ns \\
\hline PZB & 41.61 & 2.32 & 37.60 & 44.54 & 10 & $* *$ & 44.19 & 1.80 & 39.98 & 47.43 & 34 & . & 45.13 & 1.68 & 41.52 & 48.55 & 30 & ** \\
\hline PPB & 7.04 & 0.65 & 6.44 & 8.40 & 10 & ns & 7.38 & 0.62 & 6.24 & 8.60 & 37 & * & 7.77 & 0.61 & 6.45 & 8.79 & 34 & ns \\
\hline LAB & 17.90 & 0.67 & 16.99 & 18.76 & 6 & $* *$ & 19.42 & 1.19 & 17.14 & 22.36 & 37 & ns & 19.01 & 1.26 & 16.34 & 21.20 & 34 & ns \\
\hline CIL & 68.42 & 3.30 & 61.30 & 71.16 & 10 & $* \star$ & 72.84 & 2.97 & 65.43 & 77.58 & 37 & ns & 73.52 & 2.99 & 67.44 & 79.16 & 32 & ns \\
\hline$Z L$ & 27.38 & 1.02 & 25.90 & 29.44 & 10 & $\star \star *$ & 29.03 & 1.33 & 25.56 & 31.39 & 38 & ns & 29.40 & 1.48 & 26.25 & 32.96 & 32 & ns \\
\hline BNA & 10.56 & 0.70 & 9.30 & 11.35 & 9 & $* *$ & 11.67 & 0.93 & 9.50 & 13.37 & 36 & $* *$ & 10.97 & 0.90 & 9.23 & 13.12 & 32 & * \\
\hline HIF & 9.31 & 0.76 & 7.67 & 10.65 & 10 & ns & 9.13 & 0.87 & 6.78 & 10.37 & 39 & ns & 9.21 & 0.81 & 7.48 & 10.97 & 32 & ns \\
\hline BIF & 3.06 & 0.31 & 2.66 & 3.43 & 6 & ns & 3.44 & 0.51 & 2.53 & 4.55 & 35 & $\star \star *$ & 3.78 & 0.42 & 3.09 & 5.26 & 34 & * \\
\hline BIT & 5.32 & 1.08 & 4.00 & 7.38 & 10 & $\star \star *$ & 6.19 & 0.54 & 5.03 & 7.40 & 38 & ns & 6.20 & 0.51 & 5.15 & 7.17 & 33 & ns \\
\hline DI & 3.46 & 0.31 & 3.07 & 3.91 & 10 & ns & 3.57 & 0.27 & 3.90 & 4.39 & 36 & ns & 3.70 & 0.26 & 2.99 & 4.38 & 33 & ns \\
\hline MTR & 14.55 & 0.70 & 13.60 & 15.73 & 10 & $* *$ & 15.86 & 0.72 & 14.66 & 17.54 & 37 & $* *$ & 16.39 & 0.68 & 14.80 & 17.68 & 34 & * \\
\hline LM & 10.76 & 0.41 & 10.20 & 11.33 & 10 & $* *$ & 11.87 & 0.58 & 10.75 & 13.43 & 37 & ns & 11.79 & 0.48 & 10.80 & 12.66 & 34 & ns \\
\hline BP4 & 4.25 & 0.29 & 3.80 & 4.66 & 10 & ns & 4.45 & 0.29 & 3.83 & 5.16 & 38 & $\star \star *$ & 4.70 & 0.28 & 3.92 & 5.12 & 34 & ns \\
\hline BM1 & 4.09 & 0.13 & 3.90 & 4.35 & 10 & ns & 4.22 & 0.22 & 3.72 & 4.68 & 37 & 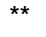 & 4.41 & 0.22 & 3.85 & 4.86 & 32 & ns \\
\hline LDE & 40.81 & 1.99 & 38.37 & 44.18 & 6 & ns & 42.09 & 1.88 & 38.78 & 46.59 & 35 & $* *$ & 43.68 & 2.49 & 38.66 & 48.96 & 33 & * \\
\hline HDE & 21.83 & 1.15 & 20.55 & 23.83 & 6 & ns & 22.35 & 1.07 & 20.27 & 24.59 & 35 & ns & 22.61 & 1.68 & 19.33 & 25.86 & 33 & ns \\
\hline $\mathrm{LH}$ & 60.71 & 10.34 & 38.14 & 72.84 & 10 & * & 85.98 & 23.71 & 55.11 & 125.34 & 34 & ns & 91.68 & 17.09 & 59.52 & 123.79 & 30 & ns \\
\hline LQ & 35.17 & 3.50 & 30.97 & 41.01 & 10 & $* *$ & 45.65 & 9.63 & 33.01 & 67.27 & 34 & $* *$ & 57.74 & 4.80 & 44.69 & 68.47 & 30 & ** \\
\hline HFL & 66.00 & 3.92 & 60.00 & 73.00 & 7 & ns & 62.15 & 7.27 & 49.00 & 80.00 & 26 & $\star \star$ & 73.33 & 6.88 & 65.00 & 85.00 & 12 & ** \\
\hline EAR & 20.86 & 4.74 & 11.00 & 25.00 & 7 & ns & 19.32 & 5.28 & 10.00 & 30.00 & 25 & ns & 18.00 & 4.88 & 12.00 & 25.00 & 12 & ns \\
\hline W & 1330.00 & 417.40 & 1150.00 & 1600.00 & 7 & ns & 1546.63 & 306.11 & 1020.00 & 2004.00 & 16 & ns & 1638.36 & 371.66 & 1087.00 & 2140.00 & 11 & ns \\
\hline
\end{tabular}

count, suggesting isolation by distance, but not within the three groups, which indicates gene flow within these groups.

The external morphological characters of the Northern group fit the description of C. insidiosus given by Voss \& Angermann (1997): a small hairy porcupine with short bicolor mesodorsal quills (30-35 $\mathrm{mm}$ ) that are concealed by long, soft, pale or pale-based fur; ventral surface covered exclusively with short fur; uniformly darkish vibrissae and ventral bristles on the tail. We used skull measurements from Voss \& ANGERMAnN (1997) in our morphometric analyses, including those from the holotype of $C$. insidiosus, and found them to fit better the members of the Northern group (see Fig. 42). In our sample, representatives of the Northern group have the shortest maxillary toothrows (MTR) and molars (LM), which are significantly different from the other two groups, confirming a diagnostic trait of C. insidiosus (Voss \& Angermann 1997). The type locality of C. insidiosus is Salvador, state of Bahia, Brazil as defined by Voss \& ANGERMANN (1997), and it falls within the range of the Northern group.

Emmons \& FeER (1997) suggested that the hair of $C$. insidiosus varies from grayish to brown. We found uniformly dark-brown hairs in specimens of the Northern group (Figs 30 and 31) from Ilhéus, state of Bahia, and Santa Teresa, state of Espírito Santo, which had no tricolor quills. Moojen (1952) and Voss \& ANGERMann (1997) suggested that specimens with these characters might belong to C. affinis. These authors, however, emphasized the presence of orange-tipped tricolor quills on the head, nape, and shoulders of C. affinis. Recently, Voss (2011) listed C. affinis as a synonym of C. spinosus. Although we found no specimen with both dark-brown dorsal pelage and tricolor 
Table IV. Correlation between geographic distance (GD) and morphometric distance among and within groups of Coendou spp. from eastern Brazil. $\left({ }^{* *}\right) p>0.99,\left({ }^{*}\right) p>0.975$, (ns) non significant, (MeD) overall morphometric distance given by the combination of all measurements. See text for measurement abbreviations.

\begin{tabular}{|c|c|c|c|c|c|c|c|c|}
\hline \multirow{2}{*}{ Matrix } & \multicolumn{2}{|c|}{ All specimens } & \multicolumn{2}{|c|}{ Northern group (C. insidiosus) } & \multicolumn{2}{|c|}{ Central group (C. spinosus) } & \multicolumn{2}{|c|}{ Southern group (C. spinosus) } \\
\hline & Correlation & $\mathrm{p}$ & Correlation & $\mathrm{p}$ & Correlation & $\mathrm{p}$ & Correlation & $\mathrm{p}$ \\
\hline$G D \times L N$ & 0.044 & ns & 0.273 & ns & -0.059 & ns & 0.050 & ns \\
\hline$G D \times B B$ & 0.133 & * & 0.141 & ns & 0.019 & ns & -0.038 & ns \\
\hline$G D \times L D$ & -0.076 & ns & -0.149 & ns & -0.088 & ns & -0.090 & ns \\
\hline GD $\times$ PZB & 0.257 & ** & 0.364 & ns & -0.110 & ns & 0.054 & ns \\
\hline $\mathrm{GD} \times \mathrm{APB}$ & -0.045 & ns & 0.375 & ns & 0.171 & ns & -0.018 & ns \\
\hline $\mathrm{GD} \times \mathrm{PPB}$ & -0.005 & ns & -0.051 & ns & -0.065 & ns & 0.059 & ns \\
\hline$G D \times L A B$ & 0.070 & ns & -0.110 & ns & -0.014 & ns & 0.112 & ns \\
\hline $\mathrm{GD} \times \mathrm{CIL}$ & 0.176 & $* *$ & 0.574 & ns & 0.015 & ns & 0.022 & ns \\
\hline$G D \times Z L$ & 0.179 & $* *$ & 0.398 & ns & 0.022 & ns & 0.024 & ns \\
\hline$G D \times B N A$ & -0.016 & ns & 0.287 & ns & -0.080 & ns & -0.072 & ns \\
\hline GD $\times$ HIF & -0.051 & ns & -0.042 & ns & 0.043 & ns & -0.062 & ns \\
\hline GD $\times$ LIF & -0.045 & ns & -0.027 & ns & -0.095 & ns & -0.082 & ns \\
\hline $\mathrm{GD} \times \mathrm{BIF}$ & 0.142 & ** & -0.314 & ns & 0.060 & ns & -0.074 & ns \\
\hline$G D \times B I T$ & 0.166 & * & 0.602 & ** & -0.117 & ns & -0.094 & ns \\
\hline$G D \times D I$ & 0.042 & ns & 0.732 & ns & 0.053 & ns & -0.144 & ns \\
\hline $\mathrm{GD} \times \mathrm{MTR}$ & 0.326 & $* *$ & 0.561 & $* *$ & 0.100 & ns & -0.038 & ns \\
\hline $\mathrm{GD} \times \mathrm{LM}$ & 0.202 & $* *$ & 0.411 & ns & -0.004 & ns & 0.030 & ns \\
\hline $\mathrm{GD} \times \mathrm{BP} 4$ & 0.131 & $*$ & 0.324 & ns & 0.047 & ns & -0.153 & ns \\
\hline GD x BM1 & 0.114 & * & 0.028 & ns & -0.070 & ns & -0.071 & ns \\
\hline GD $\times$ LDE & 0.079 & ns & -0.055 & ns & -0.042 & ns & -0.070 & ns \\
\hline $\mathrm{GD} \times \mathrm{HDE}$ & -0.067 & ns & -0.086 & ns & 0.031 & ns & -0.105 & ns \\
\hline$G D \times M e D$ & 0.228 & $* *$ & 0.477 & ns & -0.067 & ns & -0.029 & $\mathrm{n}$ \\
\hline
\end{tabular}

quills, we recorded two animals with light-brown and pale dorsal pelage with tricolor quills on the head, nape, and shoulders, which were collected at Caravelas, state of Bahia, and São Mateus, state of Espírito Santo. They also show yellow-tipped ventral bristles on the tail, a diagnostic character of $C$. affinis (Voss \& Angermann 1997). We thus raise the possibility that $C$. affinis might be a phenotypic variant of $C$. insidiosus, and not C. spinosus as suggested by Voss (2011). Unfortunately, the type of $C$. affinis is a mounted skin only, and the type locality is indefinite, therefore the application of this name is likely to remain problematic (Voss 2011).

Husson (1978) argued that C. melanurus (type locality: Barra, Rio Negro, Amazonas, Brazil) is a junior synonym of $C$. insidiosus, as suggested by CABrera (1961). EMmons \& Feer (1997) pointed out that C. melanurus occurs in northern Amazonia (Brazil, Colombia, Venezuela, Suriname, Guyana and French Guiana). After analyzing the type series of C. melanurus, Voss \&ANGERMANN (1997) argued that specimens are externally and cranially longer than $C$. insidiosus. In addition, C. melanurus has thickly streaked yellow or ivory-white dorsal pelage, a striking effect caused by the admixture of predominantly blackish wool hairs with much longer, coarser, pale-tipped guard hairs (Voss \& Angermann 1997). We found no specimen that fits this description among individuals of Coendou form eastern Brazil. Thus, we agree that C. melanurus is distinct from C. insidiosus, as proposed by several authors (Tate 1935, Moojen 1952, Ellerman 1966, Handley \& Pine 1992, Emmons \& Feer 1997, Voss \& Angermann 1997, Eisenberg \& Redford 1999, Woods \& Kilpatrick 2005).

According to Emmons \& FeER (1997), C. insidiosus ranges from the Northern state of Espírito Santo to the coast of Bahia. Although Oliver \& SANTos (1991) reported this species from the state of Sergipe to the northern part of the state of Rio de Janeiro, they based their work on interviews, sightings, and signs in addition to vouchers, and the correct identification of Coendou species is very uncertain without voucher specimens. We recorded C. insidiosus (the Northern group) from the northern coast of the state of Bahia to central state of Espírito Santo, reaching the northeastern portion of the state of Minas Gerais (Fig. 17). In addition to museum records, there are pictures of $C$. insidiosus (Rivelino T. S. Galvão, pers. comm.) from Parque Estadual Paulo César Vinha, southern state of Espírito Santo. These data show 
that Rio Doce is not the southern distributional limit of $C$. insidiosus, as suggested by Voss \& Angermann (1997).

Specimens we classified in the Central group fit closely the description of Coendou spinosus given by Voss (2011): a small hairy porcupine covered with long quills (40-80 $\mathrm{mm}$ on middorsum), which are tricolor over the head, shoulders, middle back, flanks, thighs, and sides of the tail; dark-based hairs and grayish (Figs 24 and 25), orange (Figs 32 and 33) or yellow (Figs 34 and 35) tips; vibrissae and ventral caudal bristles conspicuously bicolored, both showing dark bases and pale tips; and maxillary toothrow and molars longer than those of $C$. insidiosus. Voss (2011) designated a neotype for C. spinosus, collected by William Foster at Sapucay, in the Paraguayan department of Paraguarí. Voss \& ANGERMAnN (1997) suggested that small hairy Brazilian porcupine populations are C. spinosus, a senior synonym of C. villosus, C. nigricans, C. sericeus, and C. roberti according to them. In his original descriptions of $C$. villosus and $C$. spinosus, Cuvier (1823) distinguished these two species by the presence of several long and thick hairs that completely cover the dorsal and lateral quills in the former, but not in the latter (see also Moojen 1952), as their species names imply. These long and thick hairs are evident in the Central group, and assuming that C. villosus and C. spinosus are distinct species (following Cuvier 1823, Husson 1978, and Woods \& Kilpatrick 2005), the appropriate name for our Central group might be $C$. villosus. However, considering that the holotype of C. villosus is actually lost and its type locality is unknown (Voss 2011), the application of this name is problematic and should be avoided until future research clarifies its identity.

The general color of the dorsal pelage in Coendou results from the combination of independent factors, mainly hair base color, hair tip color, quill color, and ratio of color bands on quills. The number of possible combinations among these factors is responsible for the large phenotypic variation in the body color of specimens, which explains historical difficulties in species identification. We found that some specimens of $C$. spinosus have light-brown hair tips (Figs 36 and 37), and that most of them have orange bristle tips on the ventral part of the tail. Hairs and quills of specimens of the Central group are longer than those of C. insidiosus, confirming Voss \& Angermann's (1997) observations for C. spinosus. The tricolor quills cover from the head to the mesodorsal or lumbar region in C. spinosus, and their yellow band is longer than the black and orange bands (Fig. 19). In addition to longer maxillary toothrows and molars, C. spinosus has longer and wider skulls, auditory bullae and zygomatic arch, larger nasal apertures, and wider incisors than C. insidiosus.

Based mainly on pelage color, Emmons \& FeER (1997) described a specimen collected in the state of Espírito Santo as a possible hybrid between C. spinosus and C. insidiosus, and suggested that this region could represent a hybrid zone of these species. On the other hand, Voss \& Angermann (1997) stated that this specimen is a subadult $C$. spinosus, because of the pres- ence of tricolor quills, darkish-based dorsal hairs, bicolored vibrissae and ventral bristles on the tail, and maxillary toothrow longer than $C$. insidiosus. The phenotypic variation found in the present study indicates that the specimen described by EMmONs \& FEER (1997) is indeed C. spinosus, especially considering the darkish-based dorsal hairs and large maxillary toothrow.

One of the junior synonyms of C. spinosus is C. sericeus from the type locality São João do Monte Negro, $28^{\circ} \mathrm{S}$, state of Rio Grande do Sul, Brazil (Cabrera 1961, Woods \& Kilpatrick 2005). According to Moojen (1952), C. sericeus has many dorsal hairs with dark-brown base and whitish tip covering blackbased, yellow-tipped quills. This form is likely a phenotypic variant of C. spinosus, because it has many long dorsal hairs completely covering the quills. However, we cannot confirm the taxonomic status of $C$. sericeus based on our data. Although we found some specimens of $C$. spinosus with dark-brown based, whitish (grayish) tipped dorsal hairs, none of them had black based, yellow tipped quills.

The specimen described by Cuvier as $C$. spinosus showed few dorsal hairs covering dorsal and lateral quills (see Moojen 1952). This is a key feature we found in the Southern group, because their quills are long and reach nearly the same length as most dorsal hairs. The specific epithet paragayensis is unavailable because OKEN (1816) is a non-Linnaean work (Voss \& ANGERMANN 1997). But EMmons \& FeER (1997) illustrated C. paragayensis as a small porcupine with the dorsal surface yellowish anteriorly, and dark-brown around the lumbar region, which is dominated by long yellowish or yellow-tipped quills. We found specimens with these characters among members of the Southern group (Figs 38 and 39). Coendou spinosus usually shows tricolor quills that completely cover the dorsal surface. These quills have equal-length yellow and black bands, which are longer than the orange band (Fig. 20). Some specimens have yellow-tipped quills (Fig. 21). The ventral bristle tips on the tail are usually yellow.

Moojen (1952) also described C. spinosus as having the dorsal surface dominated by quills and an orange coloration. He wrote about $C$. roberti, known only from the type locality (Roça Nova, Serra do Mar, railway between Paranaguá and Curitiba, state of Paraná, Brazil), which has few hairs covering the dorsal yellowish quills. Moojen (1952) also described C. nigricans (type locality: Brazil) as having darkish dorsal pelage and few hairs covering the dorsal and lateral quills. We found specimens that fit the above descriptions and also some intermediary forms among C. spinosus (Figs 40-41, 38-39, and 26-27, respectively). Therefore, our data is in agreement with the ideas that $C$. roberti and $C$. nigricans are phenotypic variants and therefore should be treated as junior synonyms of C. spinosus (Voss 2011).

According to Woods \& Kilpatrick (2005), C. spinosus is distributed in Paraguay, eastern and southern Brazil, Uruguay, and northeastern Argentina. We recorded specimens in Brazil from the state of Espírito Santo to the state of Rio Grande do Sul, extending into eastern state of Minas Gerais (Fig. 17). The northernmost record is at Povoação, Linhares, on the coast of 
the state of Espírito Santo, a few kilometers north of the mouth of Rio Doce, indicating sympatry between C. spinosus and C. insidiosus in the state of Espírito Santo. Given that their distributions overlap, the possibility of hybrids between these two species (EMmons \& FeER 1997) mentioned above cannot be completely discarded.

In southern Brazil, C. spinosus from the Central group were found along the coast, whereas most specimens of the Southern group were collected mostly inland. The latter group occupies the southernmost range, and consequently the coolest environment among eastern Brazilian porcupines, despite having the least dense fur when compared to specimens of the Northern and Central groups. These data contradict Handley \& PINE (1992), who suggested that the amount and length of hairs covering the dorsal quills should increase with increasing latitudes (and decreasing temperatures). This geographic variant of C. spinosus might have evolved other physiological mechanisms to compensate for its scarce hair.

In conclusion, we found three spatially coherent, morphologically distinct groups, diagnosable using a combination of discrete morphological characters, and supported by univariate and multivariate statistical analyses. We classified members of the Northern group as C. insidiosus, which are cranially and externally smaller than the other two groups, and have shorter hairs and quills. Specimens of the Central group are intermediate in terms of body size, and fit the description of C. spinosus, which have thick hairs covering the dorsal and lateral quills. The Southern group has the largest body size and we classified it as a geographic variant of C. spinosus based on the conspicuous presence of large quills on the dorsal surface.

\section{ACKNOWLEDGMENTS}

We thank the following curators and staff for making specimens available: Gustavo Fonseca and Raquel Moura (UFMG), Marlene Hoffmann and Helio Fernandes (MBML), Márcia Jardim and Daniela Sanfelice (MCNFZB), Teresa C.C. Margarido and Gilda M.S. Tebet (MHNCI), Mario de Vivo and Juliana G. Barros (MZUSP), João A. de Oliveira, Stella Franco and Sérgio M. Vaz (MN), Simone Lóss (UFES). We thank João A. de Oliveira, Sérgio L. Mendes and Louise Emmons for kindly reviewing earlier drafts of this paper. VCJr had fellowship support from Coordenação de Aperfeiçoamento de Pessoal de Nível Superior (Capes, Brazil) and YL has a scholarship from Conselho Nacional de Desenvolvimento Científico e Tecnológico (CNPq, Brazil). Additional financial support was provided by Programa Taxonomia from CNPq, and the Oliver Pearson Award from the American Society of Mammalogists (to YLRL). We thank Sílvia Ramira Lopes Pinto and our colleagues from the Laboratório de Mastozoologia e Biogeografia at Universidade Federal do Espírito Santo, especially Leonora P. Costa, Bárbara M. de A. Costa, Simone Lóss, and Ana C. Loss for continuous support and encouragement throughout this work.

\section{LITERATURE CITED}

Bonvicino, C.R.; F.C. Almeida \& R. Cerqueira. 2000. The karyotype of Sphiggurus villosus (Rodentia: Erethizontidae) from Brazil. Studies on Neotropical Fauna \& Environment 30: 81-83.

Bonvicino, C.R.; V. Penna-Firme \& E. Braggio. 2002. Molecular and karyologic evidence of the taxonomic status of Coendou and Sphiggurus (Rodentia: Erethizontidae). Journal of Mammalogy 83 (4): 1071-1076.

Cabrera, A. 1961. Catalogo de los mamiferos de America der Sur. Revista del Museo Argentino de Ciencias Naturales "Bernardino Rivadavia" Ciencias Zoológicas 4 (2): 309-732.

Cuvier, F.G. 1823. Examen des especes formation des genres ou sous-genres Acanthion, Eréthizon, Sinéthère et Sphiggure. Mémoires du Muséum d'Histoire Naturelle (Paris) 9: 413484.

EISENBERG, J.F. \& K.H. REDFoRd. 1999. Mammals of the Neotropics - The Central Neotropics. Ecuador, Peru, Bolivia, Brazil. Chicago, The University of Chicago Press, vol. 3, 609p.

ELLERMAN, J.R. 1966. The families and genera of living rodents. British Museum Press, London, 690p.

EMmons, L.H. \& F. FeER. 1997. Neotropical rainforest mammals: a field guide. Chicago, The University of Chicago Press, $2^{\text {nd }}$ ed., 216-223p.

ESRI. 1992-1999. ArcView GIS 3.2. Environmental Systems Research Institute, Inc., Redlands.

Geobusca. 2007. Banco de Dados Geoespacial para usuários de GPS. Available online at: http://www.geobusca.net [Accessed: 21/07/2007].

Hammer, O.; D.A.T. Harper \& P.D. Rayn. 2001. PAST: Paleontological statistics software package for education and data analysis. Paleontologia Eletronica 4 (1): 1-9.

Handley JR, C.O. \& R.H. Pine. 1992. A new species of prehensiletailed porcupine, genus Sphiggurus Lacépède, from Brazil. Mammalia 56: 237-244.

Husson, A.M. 1978.The mammals of Suriname. Leiden, E.J. Brill, Zoölogische Monographeieen van het Rijksmuseum van Natuurlijke Historie, 569p.

Leite, Y.L.R.; V. Caldara Jr; A.C. Loss; L.P. Costa; E.R.A. Melo; J.R. Gadelha \& A.R.M. Pontes. 2011. Designation of a neotype for the Brazilian porcupine, Coendou prehensilis (Linnaeus, 1758). Zootaxa 2791: 30-40.

Lima, J.F.S. 1994. Cariótipos em espécies de Dasyproctidae e Erethizontidae, com discussão da evolução cromossômica (Rodentia, Caviomorpha). Brazilian Journal of Genetics 3 (17): 135-135.

Marroig, G. \& J.M. Cheverud. 2001. A comparison of phenotypic variation and covariation patterns and the role of phylogeny, ecology, and ontogeny during cranial evolution of New World monkeys. Evolution 55 (12): 2576-2600.

Marroig, G. \& J.M. Cheverud. 2004. Did natural selection or genetic drift produce the cranial diversification of Neotropical monkeys? The American Naturalist 163 (3): 417-428. 
Marroig, G. \& J.M. Cheverud. 2005. Size as a line of least evolutionary resistence: diet and adaptive morphological radiation in New World monkeys. Evolution 59 (5): 1128-1142.

Moojen, J. 1952. Os roedores do Brasil. Rio de Janeiro, Biblioteca Científica Brasileira, Séria A-II, 214p.

Moraes-SAntos, H.M. 1997. Descrição do sincrânio de Coendou prehensilis (Erethizontidae) em comparação com Proechimys guyannensis guyannensis (Echimyidae) (Rodentia, Caviomorpha). Boletim do Museu Paraense Emílio Goeldi 13 (2): 95-198.

OKEN, L. 1816. Lehrbuch der Naturgeschichte. Zoologie. Jena, August Schmid und Comp., vol. 3, 1270p.

Oliver, W.L.R. \& I.B. SANTOS. 1991. Threatened endemic mammals of the Atlantic Forest region of South-East Brazil. Wildlife Preservation Trust, Special Scientific Report 4: 1-126.

Paynter, R.A. \& M.A. Traylor. 1991. Ornithological gazetteer of Brazil. Cambridge, Harvard University, Bird Department, Museum of Comparative Zoology, 789p.

SokaL, R.R. \& F.J. Rohlf. 1995. Biometry. New York, W.H. Freeman and Company, $3^{\text {rd }}$ ed., $887 p$.

TATE, G.H.H. 1935. The taxomony of the genera of Neotropical hystricoid rodents. Bulletin of the American Museum of Natural History 68: 1-447.
VAnzolini, P.E. 1992. A supplement to the Ornithological Gazetteer of Brazil. São Paulo, Museu de Zoologia, Universidade de São Paulo, 252p.

Voss, R.S. 2011. Revisionary Notes on Neotropical Porcupines (Rodentia:Erethizontidae) 3. An Annotated Checklist of the Species of Coendou Lacépède, 1799.American Museum Novitates 3720: 1-36.

Voss, R.S. \& R. Angermann. 1997. Revisionary notes on Neotropical porcupines (Rodentia: Erethizontidae). 1. Type material descrided by Olfers (1818) and Kuhl (1820) in de Berlin Zoological Museum. American Museum Novitates 3214: 1-42.

Voss, R.S. \& M.N.F. SiLva. 2001. Revisionary notes on Neotropical porcupines (Rodentia: Erethizontidae). 2. A review of Coendou vestitus Group with Descriptions of Two New Species from Amazonia. American Museum Novitates 3351: 1-36.

Woods, C.A. \& C.W. KiLPATRICK. 2005. Suborder Hystricognathi. In: D.E. WILSON \& D.M. REEDER (Eds). Mammal species of the world. A taxonomic and geographic reference. Baltimore, Johns Hopkins University Press, $3^{\text {rd }}$ ed., vol. 2, 2000p.

Submitted: 06.IX.2011; Accepted: 05.VII.2012.

Editorial responsibility: Walter A. Boeger

Appendix. Specimens of Coendou examined and collecting localities in Brazil. Latitude and longitude are in parentheses, expressed as negative decimal degrees. For scientific collection acronyms, see Materials and Methods. Localities are grouped by Brazilian states, which are listed from north to south.

Coendou insidiosus (Northern group):

Bahia: UFES 136 - Fazenda Elma, Nova Viçosa (-17.98 -39.56); UFES 137 - Fazenda Monte Castelo, Caravelas (-17.79 -39.26); MN 1361 - Feira de Santana (-12.25 -38.96); MN 11210 - Fazenda Ibaiti, Banco da Vitória, Ilhéus (-14.82 -39.027); MN 11211 - Fazenda Pirataquissé, Banco da Vitória, Ilhéus (-14.78 -39.028); MN 11466, MN 11467, MN 68199 and MN p17301 - Ilhéus (-14.78 -39.04); MN 55527 - Porto Seguro (-16.44 -39.07).

Espírito Santo: MBML 2347 - Guriri, São Mateus (-18.54 -39.73); MN 8277 - Rio São José (-19.17 -40.20).

Coendou spinosus (Central group):

Espírito Santo: UFES 928 and MBML 1840- Estação Biológica de Santa Lúcia, Santa Teresa (-19.96 -40.54); MBML 2130 - Rodovia Josil Espíndula, Três Barras, Fundão (-19.93 -40.45); MBML 1956 - Sítio Ipê, Rio Nove, Santa Maria do Jetibá (-20.05 -40.70); MBML 2129 - Reserva Biológica Augusto Ruschi, Nova Lombardia, Santa Teresa (-19.90 -40.55); MBML 1873 - Patrimônio Santo Antônio, Santa Teresa (-19.90 -40.54); MBML 2126 - BR262, Ibatiba (-20.23 -41.57); MBML 182 - Santa Teresa (-19.94 -40.63); MBML 1783 - Rio Bonito, Santa Teresa (-19.96 -40.60); MBML 1857 - Museu de Biologia Professor Mello Leitão, Santa Teresa (-19.94 -40.58); MBML 2193 - Igreja Caravagio, São Lourenço, Santa Teresa (-19.93 -40.61); MBML 2226 - Rodovia Josil Espíndula, km 26, Santa Teresa (19.96 -40.51); MBML 2268 - Estrada Linhares x Povoação, km 11, Linhares (-19.48 -40.09); MBML 1822 - Fazenda Bronzon, Santa Teresa (-19.90 -40.56); MBML 1826 - Buerão, Santa Teresa (-19.96 -40.53); MBML 1827 - Santa Teresa (-19.94 -40.64); MBML2174 - Restinga de Setiba, Guarapari (-20.62 -40.43); UFES 1183 - Morro do Moreno, Vila Velha (-20.33 -40.28); MN 68200 (sem cidade).

Rio de Janeiro: MN 254, MN 255, and MN 256 - Rio de Janeiro (-22.91 -43.21); MN 2234, MN 2235 and MN 7260 - Teresópolis (-22.42 -42.96); MN 5514 and MN M3063 - Fazenda da Lapa, Mangaratiba (-22.95 -44.03); MN 8239, MN 8240, MN 8341, MN 8242, MN 46517, MN 46518, MN 46519, and MN 46520 - Pedra Branca, Parati (-23.18 -44.78); MN 19327 - Alto Mosella, Petrópolis (-22.51 43.18); MN 30494 - Enseada de Palmas, Ilha Grande, Angra dos Reis (-23.01 -44.32); MN c152 - Ilha Grande, Angra do Reis (-23.16 -44.23); MN 42815, and MN 46936 - Restinga da Barra de Marica, Maricá (-22.95 -42.83); MN 46937 - Sumidouro (-22.05 -42.69); MN 46938 - Morro de São João, Casimiro de Abreu (-22.49 -42.20); MN 59613 - Fazenda Providência, Carmo (-21.94 -42.60).

Minas Gerais: UFMG 990 - Caratinga (-19.79 -42.14); UFMG 1564 - Área de Proteção Especial de Serra Azul, Mateus Leme (-19,99 44,43); MN 1365 - Viçosa (-20.76 -42.88); MN 30583 - BR040, km 24, Ressaquinha (-21.07 -43.77); MN (no number) - Mata da Penha, Passos (-20.97 -46.51); MN (sem número) - Caixa da Areia, Belo Horizonte (-19.89 -43.95). 
São Paulo: MZUSP 1816, MZUSP 1817, MZUSP 1818, MZUSP 1819 and MZUSP 1905 - Ubatuba (-23.46 -45.08); MZUSP 5871 - Guará (-20.43 -47.823); MZUSP 6282 and MZUSP 6283 - Vila Oliveira, Mogi das Cruzes (-23.53 -46.17); MZUSP 2342 and MZUSP 2930 - São Paulo (-23.58 -46.62); MZUSP 10310 - Barro Branco, São Paulo (-23.77 -46.68); MZUSP 360 and MZUSP 1985 - Ipiranga, São Paulo (-23.59 -46.60); MZUSP 1177 - Franca (-20.53 -47.38); MZUSP 25237 - Vila Barra de Icapara (-24,68 -47,47); MZUSP 327 Osasco (-23.57 -46.78); MZUSP 3706 - Itatiba (-23.01 -46.84); MZUSP 6195 - Monte Alegre do Sul (-22.68 -46.68); MZUSP 10424 and MZUSP 10428 - Primeiro Morro, Juquiá (-24.38 -47.79); MZUSP 32321, MZUSP 32322 and MZUSP 32324 - Biritiba Mirim (23.58 -46.03); MZUSP 23949 - Ibiúna (-23.66 -47.21); MZUSP 32202 - Caieiras (-23.37 -46.73); MHNCI 3024 - Ariri, Cananéia (25,02 -47,95); UFMG 3043 - Floresta Nacional de Ipanema, Sorocaba (-23.43 -47.63).

Paraná: MHNCI 2591 - Ararapira, Ilha do Superagui, Guaraqueçaba (-25.35 -48.41).

Santa Catarina: MZUSP 5870 - Lagoa (-27.60 -48.47).

Rio Grande do Sul: MCNFZB 377 - Estrada Canela, km 15, São Francisco de Paula (-29.44 -50.58); MCNFZB 592 - Tupanciretã (-29.09 -53.85); MCNFZB 1020, MCNFZB 2680 and MCNFZB 2681 - Fazenda Sanga da Porteira, Viamão (-30.10 -50.97).

\section{Coendou spinosus (Southern group):}

São Paulo: MZUSP 6489 - São Paulo (-23.58 -46.62); MZUSP 10330 - Fazenda Pedras, Avaré (-23.10 -48.94); MZUSP 6271 - Fazenda Palmeira, Assis (-22.66 -50.41); MZUSP 6677 - Capão Grande, Botucatu (-22.89 -48.45);

Paraná: MHNCI 278 - Cubatão, Baía de Guaratuba, Guaratuba (-25.93 -48.58); MHNCI 350 and MHNCI 3934 - Passeio Público, Curitiba (-25.42 -49.27); MHNCI 479 - Curitiba (-25.43 -49.28); MHNCI 1296 - Mercês, Curitiba (-25.42 -49.29); MHNCI 2592 Cidade Industrial, Curitiba (-25.50 -49.34); MHNCI 3425 - Parque Regional do Iguaçu, Boqueirão, Curitiba (-25.50 -49.24); $\mathrm{MHNCl}$ 3426 - Capão Raso, Curitiba (-25.50 -49.29); MHNCI 277 - Timoneira, Almirante Tamandaré (-25.30 -49.32); MHNCl 2695 Estrada do Cerne, km 17, Almirante Tamandaré (-25.31 -49.33); MHNCI CTax6985 - Distrito de Campo Magro, Lavrinha, Almirante Tamandaré (-25.30 -49.32); MHNCI 484 - Serra do Rio Negro (-26.18 -49.67); MHNCI 1099 - Represa de Guaricana, São José dos Pinhais (-25.59 -49.23); MHNCI 1294 - Chácara Irati, Estrada Timbú Velho x Rio Timbú, Campina Grande do Sul (-24.31 -52.40); MHNCl 1297 - Represa do Capivari, Campina Grande do Sul (-25.25 -49.10); MHNCl 1295 - Tunas, Bocaiuva do Sul (-25.20 49.11); $\mathrm{MHNCI} 1298$ - Cidade Industrial, Araucária (-25.55 -49.38); MHNCl 2694 - Thomaz Coelho, Araucária (-25.54 -49.36); MHNCI 3410 - Vila de Superagui, Guaraqueçaba (-25.30 -48.32); MHNCI 2696 - Foz do Rio da Divisa, Pinhão (-25.70 -51.66); $\mathrm{MHNCl} 3203$ - Br 277, km 3, Rio Verde, Ponta Grossa (-25.09 -50.16); MHNCl 3419 - Thomaz Coelho, Quatro Barras (-25.37 49.08); $\mathrm{MHNCl} 4367$ - Avenida Dom Pedro II, 114, Quatro Barras (-25.37 -49.08); MHNCl 3917 - Salto Caxias, Três Barras do Paraná (-25.47 -53.20); MHNCI 3943 - Usina Hidrelétrica de Salto Caxias, Três Barras do Paraná (-25.51 -53.19); MHNCl 4201 andMHNCI 4202 - Usina Hidrelétrica de Salto Caxias, Flor da Serra, Boa Vista de Aparecida (-25.50 -53.37); MHNCl 4203 Usina Hidrelétrica de Salto Caxias, Foz do Chopim, Cruzeiro do Iguaçu (-25.58 -53.13); MHNCI3931 - Br 116, Rio Iguaçu, Fazenda Rio Grande (-25.66 -49.30); MHNCI 3935 - Fazenda Rio Grande (-25.66 -49.31); MHNCI 3933 - Estrada cerca de 3 km antes de Irati, Irati (-25.47 -50.65); MHNCI 3987 - Lagoa, Sede do Proação PUC/PR, Tijucas do Sul (-25.58 -53.13); $\mathrm{MHNCl} 4180-\mathrm{Br} 277$, km 205, Posto Alto do Padre Vieira, Palmeira (-25.43 -50.01); MHNCI 5772 - Br 227, km 180, Palmeira (-25.43 -50.01); MHNCI5773 - Br 227, km 181, Palmeira (-25.43 -50.01); MHNCI 4182 - Fazenda Moema, Campo Mourão (-24.05 -52.41); MHNCI 5058 - Ponte do Rio Passa Sete, Morretes (-25.49 -48.83); MHNCI 5067 - Garuva (-26.03 -48.84), MHNCI 5239 - Parque Municipal São Luis Tolosa, Rio Negro (-26.10 -49.80); MHNCI 5793 - Reservatório de Piraquara, Piraquara (-25.43 -49.07).

Santa Catarina: MZUSP 1678 - Joinville (-26,32 -48,84).

Rio Grande do Sul: MCNFZB 43 - Passo Fundo (-28.26 -52.41); MCNFZB 113 - Caçapava do Sul (-30.51 -53.48); MCNFZB 196 - São Sepé (-30.16 -53.58); MCNFZB 335 - Garruchos, São Borja (-28.66 -56.00); MCNFZB 376 - Fazenda de Ari Velho,Bom Jesus (-28.68 -50.42); MCNFZB "NE333" - Pontal das Desertas, Itapoá, Viamão (-30.10 -50.98); MCNFZB 2586 Parque Zoológico, Sapucaia do Sul (-29.80 -51.17); MCNFZB NE238 and MCNFZB NE280 - Parque Copesul, Triunfo (-29.94 -51.71); MCNFZB NE334 (sem localidade específica).

Specimens examined, but not included in statistical analyses:

Juveniles from Rio de Janeiro: MN 8243 and MN 46521 - Pedra Branca, Parati (-23.18 -44.78); MN 42814 - Rio de Janeiro (-22.91 43.21); MN 46935- Restinga da Barra de Marica, Maricá (-22.95 -42.83).

Juveniles from Paraná: MHNCI 480 - Curitiba (-25.43 -49.28); MHNCI 2697 - Foz do Rio da Divisa, Pinhão (-25.70 -51.66); MHNCI 3937 - Bairro Cachoeira, Almirante Tamandaré (-25.35 -49.26); MHNCl 4631 - Usina Hidrelétrica de Salto Caxias, Flor da Serra, Boa Vista de Aparecida (-25.50 -53.37); MHNCl 4743 - Bosque do Capão da Imbuia (MHNCl), Curitiba (-25.44 -49.22).

Unknown locality: MBML 372; UFMG 3116; MN 1362; MN 2667; MN 2669; MN 2675; MN 2683; MN 7660; MN 13352; MN 34502; MN 43942; MN 68201; MN 68202; MN 68203; MN 68204; MN p2; MN p5103; MN p5766; MN p5679; MZUSP 25234; MZUSP 25235; MHNCI 890; $\mathrm{MHNCl} 3205$.

ZOOLOGIA 29 (4): 318-336, August, 2012 